\title{
Family planning KAP survey in the Southern Region of Saudi Arabia
}

\author{
Enas A. Dhaher* \\ Female Nursing Institute, Armed Forces Hospital Southern Region of Saudi Arabia, Khamis Mushayt, Saudi Arabia
}

Received: 13 September 2017

Accepted: 06 October 2017

\section{*Correspondence:}

Dr. Enas A. Dhaher,

E-mail: enasassaf2015@gmail.com

Copyright: $\odot$ the author(s), publisher and licensee Medip Academy. This is an open-access article distributed under the terms of the Creative Commons Attribution Non-Commercial License, which permits unrestricted non-commercial use, distribution, and reproduction in any medium, provided the original work is properly cited.

\section{ABSTRACT}

Background: Family planning practices could be determined through adopting proper knowledge and positive couple attitudes towards the use of family planning which would most likely result in favourable family decisions which would benefitted both the individual and the overall country welfare.

Methods: A cross sectional study has been conducted using a structured questionnaire administered through face-toface interview to a convenient sample of 151 pregnant women attending the obstetrics and gynaecology outpatient clinic at the Armed Forces Hospital in the southern region of Saudi Arabia in December 2014.

Results: The results revealed that modern methods were popular among women. In general we found positive attitudes towards family planning among the sampled women as two third of the women have ever used contraceptives. However, the present study showed that $34 \%$ of women had unmet need of family planning. Women's age, marriage years and number of children were all found to be associated factors with unmet need.

Conclusions: National organized family planning programs might help satisfying the family planning needs for the families. Further studies regarding southern men's knowledge and attitudes towards family planning is recommended.

Keywords: Family planning, KAP, Unmet need, Saudi Arabia

\section{INTRODUCTION}

Article 16 (1) (e) of the Women's Convention requires states parties to ensure that women enjoy "rights to decide freely and responsibly on the number and spacing of their children and to have access to the information, education and means to enable them to exercise these rights". ${ }^{1}$

The Cairo International Conference on Population and Development (ICPD, 1994) acknowledged the importance of family planning in promoting the overall health and reproductive life of women. ${ }^{2}$ Ahmed, Qingfeng et al found in Global Analysis of 172 countries using the WHO data that family planning can help in reducing maternal mortality by $44 \% .^{3}$ This decrease ranged from $7 \%$ to $60 \%$ across countries. Non contraception health benefits of family planning was recognized in several previous studies as improving the child survival through lengthening the birth interval, child spacing and minimizing the siblings completion especially in limited family resources and limited national maternal resources. ${ }^{4-6}$ Studies found that oral contraceptives could help to reduce serious diseases and some gynaecological diseases among which ovarian and endometrial cancer, benign breast diseases, ectopic pregnancy and pelvic inflammatory diseases. ${ }^{7,8}$

Jensen et al recognize that women using oral contraceptives would take the advantage of her positive overall health effects. ${ }^{9}$ The main two objectives of family planning is first for a couple to have the desired number of children and second, to have proper spacing pregnancies between these children. Therefore, for achieving these objectives contraceptives were categorized into barrier, natural, chemical or surgical. ${ }^{10}$ 
WHO (1971) has early recognized that family planning is a way of living which is normally adopted voluntarily by both the woman and the couple, based on proper knowledge of family planning and contraceptives. ${ }^{11}$ In addition, the women and couples attitudes towards the use of family planning would give reasonable decisions to promote health of the family that would contribute to social development and welfare of the country. Theory of planned behaviour might help in further understanding people decisions on the use of contraceptives. ${ }^{12}$ Sound and enough knowledge of family planning methods, positive attitudes and acceptance of fertility regulations, availability of contraceptives methods, better and open communication between wife and husband of planned pregnancies, and the favourable number of children were all essential factors for effective family planning programs. ${ }^{13}$

Fertility rate Studies in Saudi Arabia had several inconsistent results, for example total fertility rate (TFR) in a study conducted by Khraif which was based on the Ministry of Planning 1999 data has been found to be 4.53, other source estimated it as 5.7.14,15 This inconsistency in recording fertility rate could be related to several factors, such as underreporting, focusing on Saudi and non-Saudi inhabitants, or geographical coverage limitations. One regional study on fertility rate in each of Oman, Egypt and Lebanon reported fertility rate as 7.1, $3.5,1.9$, respectively. ${ }^{16}$ While in Jordan TFR in 2012 was 3.5 , and the children preferences for the ideal family is four children as reported by women. ${ }^{17}$

Several studies have been conducted in Saudi Arabia to study family planning use and women's fertility preferences. For example, a study in Qaseem area of Saudi Arabia has reported that women were intended to have 5-10 children. ${ }^{18}$ Another study among female school teachers in Taeif Area of Saudi Arabia found that $40 \%$ of them were currently having three to four living children. ${ }^{19}$

Regionally, women's knowledge regarding contraceptives methods and use showed a positive progress. For example, in Egypt it has been reported that $99 \%$ of women recognize at least one modern method in the last DHS survey. ${ }^{20}$ Similar results has been found in Jordan. ${ }^{17}$ In Relation to the women's ever use of contraceptives among women in the regional area, studies have shown that $82 \%$ and $61 \%$ of married women were currently using contraceptives in Egypt and Jordan, respectively. ${ }^{20,17}$

Recently, attitudes towards family planning had improved positively in the region. For example, it has been reported that only one in ten women in Egypt disapprove the use of contraceptives. ${ }^{20}$ One regional study has indicated that $86 \%$ of Jordanian men believe that men rather than women are responsible for family planning. ${ }^{21}$ Another study in Jordan has revealed that about $95 \%$ of women in the southern region of Jordan have positive attitudes towards family planning. ${ }^{22}$
Moreover, a study conducted among Omanis adolescent perspectives on reproductive health has reported that two third of the girls and $66.6 \%$ of boys agreed that they would use contraceptive methods in the future. ${ }^{23}$ In addition, almost all women were in favor for using contraceptive methods in Gaza- Palestine. ${ }^{24}$ In Saudi Arabia, One study has revealed that the majority of women and men showed acceptance to the use of contraceptives in Qaseem region of SA. ${ }^{18}$ This study came to add to the empirical studies in SA in assessing women's knowledge, attitudes and practices towards family planning in the southern region and to explore some important factors for women's contraceptives use and unmet need.

\section{METHODS}

A cross-sectional survey of 151 Saudi women in their late third trimester (36 weeks and more) of pregnancy was conducted during the period of October to December 2014. The study took place at the Obstetrics and Gynecology outpatient clinics at the Armed Forces Hospitals Southern Region (AFHSR) in Saudi Arabia. The study site was selected as it tends to provide reproductive health care services to the entire southern region of Saudi Arabia, which include antenatal care such as high-risk pregnancy, infertility treatment, postnatal care, and family planning. Furthermore, these clinics are connected to the Obstetrics and Gynecology wards in the hospital; in average about 370 patients were seen in the clinics daily.

\section{Assessment instrument}

A structured questionnaire was used through face to face interview. The questionnaire was adapted from previous Demographic and Health Surveys (DHS) which were conducted previously in an Arabic speaking countries like Egypt and Jordan. ${ }^{20,17}$ All aspects of reproductive health and socio-demographic data were covered in this questionnaire, including family planning knowledge, attitudes and practices, as well as the problem of unmet family planning needs through several consistent and well-established questions. Based on a pilot study which was conducted with 10 women using the same setting, the questionnaire has been revised and some questions have been adapted to compensate for cultural understanding. The results of the pilot study were not included in the analysis of the current study.

\section{Sampling and data collection}

The clinics were visited five days a week starting in October and ending in December 2014. The data of the present study have been collected by the author of this article and one data collector who has a nursing background and has been trained prior to data collection about correct interviewing techniques and approaches to questions. The patients were approached after checking into the clinic during their waiting time. On average 36 
women in the later stages of their third trimester (36+ weeks of pregnancy) were assessed daily at the AFHSR Obstetrics and Gynecology clinics. Given the duration of the interview and the mean duration of visit of 8 minutes, approximately every fourth or fifth eligible woman was interviewed. The respondents were informed about the purpose of the interview and a consent form was signed prior to the interview. A total number of 160 women were approached to participate in the study and only nine women declined, which results in a response rate of $94.3 \%$. Initially, a sample size of 160 women was anticipated, assuming a $75 \%$ response rate. The total sample of 120 respondents would allow estimating proportions with $\pm 5 \%$ accuracy for the $95 \%$ confidence interval. Given the excellent response rate, the sample size of 151 women provides $80 \%$ power to detect differences of $16 \%$ or more.

\section{Study variables}

\section{Dependent variables}

Family planning knowledge, attitudes and practices were assessed through direct questions. Family planning knowledge were assessed by asking the woman first "what are the family planning methods you know". Following questions were checking all family methods by asking the woman whether she ever heard of each specific method. Women were asked regarding the preferred source of information, and whether she previously received any family planning counselling through a health care provider. Attitudes were assessed by asking the woman directly whether she is with or against the use of family planning methods and asked to give a specific rating (totally for using; for using; neutral; against using). The woman was asked about her husband attitudes as well, using the same rating scale. Family decisions regarding contraceptives use were assessed through direct questions, and how frequent she discusses family planning with her husband. Family planning practice was assessed through asking the woman whether she ever used any of each specific family planning methods (read for her). In addition, we asked about the time when she first used contraceptives and the number of children she had when she first used family planning methods. By the end of these questions, calculations for ever used and never used any contraceptive method was done and confirmed by the woman herself.

\section{Independent variables}

Several reproductive health and socio-demographic variables were assessed for their associations with ever using family planning methods. These variables included the respondent women's ages; husband age in years; women's and husband's highest level of education; as well as the difference of education between husband and wife. In addition, the respondent's current employment status and the total number of married years. Reproductive health variables included the extent of postpartum care sought in the last pregnancy; planned pregnancy and wanting this current pregnancy.

\section{Statistical analysis}

The PASW statistics 18 software was used to enter and to analyse the data. Cross tabulation and descriptive statistics were used.

\section{RESULTS}

\section{Description of the sample}

Table 1: Demographic characteristics of the sample.

\begin{tabular}{|c|c|}
\hline Characteristics & No. $151(\%)$ \\
\hline \multicolumn{2}{|l|}{ Women's age } \\
\hline $15-19$ & $2(1.3)$ \\
\hline $20-24$ & $31(20.5)$ \\
\hline $25-29$ & $46(30.5)$ \\
\hline $30-34$ & $29(19.2)$ \\
\hline $35-39$ & $35(23.2)$ \\
\hline$\geq 40$ & $8(5.3)$ \\
\hline \multicolumn{2}{|c|}{ Mean: 30 years Median: 29 years } \\
\hline \multicolumn{2}{|l|}{ Husband age } \\
\hline $20-29$ & $35(23.5)$ \\
\hline $30-39$ & $70(50.3)$ \\
\hline $40-49$ & $32(21.2)$ \\
\hline$\geq 50$ & $8(5.3)$ \\
\hline \multicolumn{2}{|l|}{ Mean: 35.1 Median:34 } \\
\hline \multicolumn{2}{|l|}{ Total number of children } \\
\hline 0 & $31(20.5)$ \\
\hline $1-2$ & $66(43.7)$ \\
\hline $3-4$ & $35(23.2)$ \\
\hline $5+$ & $19(12.6)$ \\
\hline \multicolumn{2}{|l|}{ Age at first marriage } \\
\hline$>16$ & $19(12.6)$ \\
\hline $17-20$ & $46(30.5)$ \\
\hline $21+$ & $86(57.0)$ \\
\hline \multicolumn{2}{|l|}{ Mean: 21; Median: 22} \\
\hline \multicolumn{2}{|l|}{ Marriage years } \\
\hline$<1$ & $8(5.3)$ \\
\hline $1-4$ & $36(23.8)$ \\
\hline $5-9$ & $46(30.5)$ \\
\hline $10-14$ & $40(26.5)$ \\
\hline $15-20$ & $11(7.3)$ \\
\hline$\geq 21$ & $10(6.6)$ \\
\hline \multicolumn{2}{|l|}{ Mean: $8.3 ;$ Median: 8} \\
\hline \multicolumn{2}{|l|}{ Residency } \\
\hline City & $116(76.8)$ \\
\hline Village & $35(23.2)$ \\
\hline \multicolumn{2}{|l|}{ Women's education level } \\
\hline None or primary schooling & $54(35.8)$ \\
\hline Secondary and post graduate & $97(64.2)$ \\
\hline \multicolumn{2}{|l|}{ Husbands' level of education } \\
\hline None or primary schooling & $36(23.8)$ \\
\hline Secondary and post graduate & $115(76.2)$ \\
\hline \multicolumn{2}{|l|}{ Women's working status } \\
\hline Yes & $23(15.2)$ \\
\hline No & $128(84.8)$ \\
\hline
\end{tabular}


The median age of women were 29 years old. The majority of women are having more than one child with a mean of 2.3 and a median of two children. The median age of first marriage was 22 years old. Our results also indicated that around $50 \%$ of women were married for less than ten years. One third of the sample were illiterate or had a basic school level education. Only $15 \%$ of women were currently working. Husbands in the sample have a mean age of 35 years old and $76 \%$ of them obtained secondary schooling or higher education (Table 1).

\section{Knowledge of family planning method}

Women in the study were asked first to mention all the contraceptive methods known to them before. Later all the contraceptives were read to them one by one and they have been asked directly whether they recognize the mentioned contraceptive methods or not.

Table 2: Distribution of women aged 15 to more than 40 years, having knowledge of any contraceptives (without reminder/after reminder), by age and Specific method.

\begin{tabular}{|c|c|c|c|c|c|c|c|c|c|c|c|c|c|c|}
\hline \multirow{3}{*}{$\begin{array}{l}\text { Contraceptive } \\
\text { methods }\end{array}$} & \multicolumn{14}{|c|}{ Age in years } \\
\hline & \multicolumn{2}{|c|}{$\begin{array}{l}\text { Total } \\
\text { number }\end{array}$} & \multicolumn{2}{|c|}{$15-19$} & \multicolumn{2}{|c|}{$20-24$} & \multicolumn{2}{|c|}{$25-29$} & \multicolumn{2}{|c|}{$30-34$} & \multicolumn{2}{|l|}{ 35-39 } & \multicolumn{2}{|l|}{$\geq 40$} \\
\hline & $\mathbf{W R}^{\mathbf{a}}$ & $\mathbf{A} \mathbf{R}^{\mathbf{b}}$ & WR & $\mathbf{A R}$ & WR & $\mathbf{A R}$ & WR & $\mathbf{A R}$ & WR & $\mathbf{A R}$ & WR & $\mathbf{A R}$ & WR & $\mathbf{A R}$ \\
\hline $\begin{array}{l}\text { Female } \\
\text { sterilization }\end{array}$ & 9 & 63 & 0.0 & 1.6 & 11.1 & 12.7 & 22.2 & 31.7 & 11.1 & 20.6 & 44.4 & 27.6 & 11.1 & 6.3 \\
\hline pills & 138 & 143 & 1.4 & 1.6 & 20.3 & 19.6 & 31.2 & 30.8 & 18.8 & 19.6 & 23.9 & 23.8 & 4.3 & 4.9 \\
\hline IUD & 128 & 144 & 1.6 & 1.4 & 18.8 & 19.4 & 31.3 & 30.6 & 18.8 & 20.1 & 24.2 & 22.9 & 5.5 & 5.6 \\
\hline Injections & 95 & 129 & 2.1 & 1.6 & 24.2 & 17.1 & 27.4 & 28.7 & 18.9 & 22.5 & 22.1 & 24.8 & 5.3 & 5.4 \\
\hline Implants & 46 & 85 & 2.2 & 1.2 & 19.6 & 18.8 & 32.6 & 23.5 & 19.6 & 23.5 & 15.2 & 23.5 & 10.9 & 4.7 \\
\hline Condoms & 29 & 118 & 3.4 & 0.8 & 27.6 & 17.8 & 31.0 & 30.5 & 20.7 & 22.9 & 13.8 & 23.7 & 3.4 & 4.2 \\
\hline Jell and Foam & 0 & 17 & 0.0 & 0.0 & 0.0 & 11.8 & 0.0 & 35.3 & 0.0 & 23.5 & 0.0 & 23.5 & 0.0 & 5.9 \\
\hline Breast Feeding & 14 & 99 & 0.0 & 0.0 & 21.4 & 19.2 & 28.6 & 30.3 & 7.1 & 19.2 & 33.7 & 26.3 & 7.1 & 5.1 \\
\hline Abstinence & 41 & 113 & 2.4 & 0.9 & 22.0 & 18.6 & 41.5 & 31.0 & 9.8 & 19.5 & 22.0 & 23.9 & 2.4 & 6.2 \\
\hline Withdrawal & 36 & 123 & 2.8 & 0.8 & 22.2 & 20.8 & 33.3 & 30.4 & 16.7 & 19.2 & 19.4 & 23.2 & 5.6 & 5.6 \\
\hline $\begin{array}{l}\text { Emergency } \\
\text { contraceptives }\end{array}$ & 1 & 6 & 0.0 & 0.0 & 0.0 & 0.0 & 0.0 & 66.7 & 0.0 & 16.7 & 100.0 & 16.7 & 0.0 & 6.8 \\
\hline Total Number & 151 & & 2 & & 31 & & 46 & & 29 & & 35 & & 8 & \\
\hline
\end{tabular}

${ }^{a}$ WR:\% of women who mentioned the contraceptive method without reminding, ${ }^{b}$ AR: \% of women who agreed that they know that method after reminding.

The majority of women recognized the birth spacing methods without reminder, such as Pills, Intra Uterine Devices (IUD), Injections and Implants (91.3\%, 84.7\%, $62.9 \%$ and $30.4 \%$ respectively). However, those percentages increased after reminding the women for the same birth spacing methods. Barrier Methods such as Male Condoms were mentioned without reminder by $19.2 \%$ of women, and it has increased to more than two third of women after reminder $(78.1 \%)$. On the other hand, Jell and Foam were mentioned less than condom and only after reminder $(11.2 \%)$.

Traditional methods such as Breast Feeding, Withdrawal and Abstinence were mentioned a lot more after reminding $(65.5 \%, 74.8 \%$, and $81.4 \%$ respectively) compared to what mentioned before reminding $(9.2 \%$, $23.8 \%$, and $27.1 \%$ respectively). Terminal methods were mentioned mostly by the older age group of women and only after reminding. The least mentioned methods were the Emergency methods as only six women recognize them and only after reminding. Contraceptive methods were mostly recognized among the age group of (25-29) (Table 2).

The result shows that only $4.6 \%$ of women gained their family planning information from health care providers. When it comes for choosing a contraceptive method, women preferred to consult first their husbands followed by a health care provider and then their mother $(44.4 \%$, $25.8 \%$ and $21.1 \%$ respectively) (Table 3 ).

Table 3: Percent distribution of women, by main source of family planning (F.P.) information.

\begin{tabular}{|lcl|}
\hline $\begin{array}{l}\text { Sources of family planning } \\
\text { information }\end{array}$ & Number & Percentage \\
\hline $\begin{array}{l}\text { Health care provider } \\
\text { Preferred source of information }\end{array}$ & 4.6 \\
\hline Husband & 67 & 44.4 \\
\hline Health care provider & 39 & 25.8 \\
\hline Mother & 32 & 21.2 \\
\hline Others & 12 & 8.6 \\
\hline
\end{tabular}




\section{Attitude towards family planning}

In general, women have a favourable attitude towards family planning as more than two third of women have mentioned that they are pro using family planning contraceptives.

Table 4: Women's and their husband's attitudes towards family planning.

\begin{tabular}{|c|c|c|}
\hline Attitudes towards family planning & Percent & No. \\
\hline \multicolumn{3}{|l|}{ Women's attitude towards FP } \\
\hline Totally for using & 29.8 & 45 \\
\hline For using & 48.3 & 73 \\
\hline Neural & 18.6 & 28 \\
\hline Against & 3.3 & 5 \\
\hline \multicolumn{3}{|l|}{ Husband attitude towards FP } \\
\hline Totally for using & 9.3 & 14 \\
\hline For using & 65.6 & 99 \\
\hline Neural & 15.9 & 24 \\
\hline Against & 9.3 & 14 \\
\hline \multicolumn{3}{|l|}{ Responsibility for using FP } \\
\hline Woman & 13.2 & 20 \\
\hline Husband & 19.9 & 30 \\
\hline Together & 66.9 & 101 \\
\hline \multicolumn{3}{|l|}{ Responsibility to have a new baby } \\
\hline Woman & 13.9 & 21 \\
\hline Husband & 19.2 & 29 \\
\hline Together & 66.9 & 101 \\
\hline \multicolumn{3}{|c|}{ Discussion with husband regarding FP use } \\
\hline Very Often & 4.0 & 6 \\
\hline Often & 52.3 & 76 \\
\hline Rarely & 33.8 & 51 \\
\hline Not at all & 9.9 & 15 \\
\hline \multicolumn{3}{|l|}{ Number of children when best use FP } \\
\hline No children & 4.0 & 6 \\
\hline 1 & 31.1 & 47 \\
\hline 2 & 27.2 & 41 \\
\hline 3 & 8.6 & 13 \\
\hline $4+$ & 29.1 & 43 \\
\hline
\end{tabular}

The majority of women mentioned that their husbands has also a positive attitude towards using family planning (74.9\%). Women also mentioned that mainly they have shared decisions with their husbands regarding using or stop using contraceptives.

About half of women often discuss family planning matters with their husbands. On the other hand, $29.1 \%$ of women believe that the best time to start using contraceptives is after having four children or more (Table 4).

\section{Use of family planning methods}

Our results show that the majority of women have ever used contraceptives methods (78.8\%). Almost half of the women have ever used birth spacing method pills, while $43.7 \%$ have ever used the traditional method of withdrawal. Less percentages have used the barrier method (condom) (31.1\%) followed by the IUD (29.8\%).

Table 5 presents the use of contraceptive methods by the women's age, and it shows that the pills method was mostly used among the age between 25 and 29 years old, IUD was mostly used among the age group between $35-$ 39. On the other hand, traditional methods (Withdrawal, abstinence, and breast-feeding) as well as condoms were all used among all different age groups (Table 5).

Reason for not using family planning methods. $21.9 \%$ of the interviewed women have mentioned that they have never used contraceptives. Most of these women (93.7) have mentioned that the main reason for not using contraceptives is the willingness to have children without spacing or interruption.

On the other hand, women who have stopped using contraceptives have mentioned that the main reason is the welling to have more children and wanting the current pregnancy $(43.6 \%)$.

Table 5. Percent distribution of women, who have ever used any contraceptive method, by specific method and age in years.

\begin{tabular}{|c|c|c|c|c|c|c|c|c|c|c|}
\hline \multirow[b]{2}{*}{$\begin{array}{l}\text { Age in } \\
\text { years }\end{array}$} & \multirow[b]{2}{*}{$\begin{array}{l}\mathbf{n}^{\mathbf{a}}(\%) \\
\text { of ever } \\
\text { users }\end{array}$} & \multicolumn{9}{|c|}{ Contraceptive methods } \\
\hline & & Pills & IUD $^{\mathbf{b}}$ & Injections & Implants & Condom & $\begin{array}{l}\text { Foam } \\
\text { and } \\
\text { Jell }\end{array}$ & $\begin{array}{l}\text { Breast } \\
\text { Feeding }\end{array}$ & Abstinence & Withdrawal \\
\hline $15-19$ & $1(0.8)$ & 0.0 & 0.0 & 0.0 & 0.0 & 0.0 & 0.0 & 0.0 & 2.9 & 1.5 \\
\hline $20-24$ & $17(14.3)$ & 13.5 & 13.3 & 11.1 & 27.3 & 12.8 & 50.0 & 50.0 & 14.3 & 13.6 \\
\hline $25-29$ & $40(33.6)$ & 32.4 & 24.4 & 22.2 & 27.3 & 31.9 & 25.0 & 25.0 & 28.6 & 31.8 \\
\hline $30-34$ & $23(19.3)$ & 18.9 & 17.8 & 11.1 & 9.1 & 21.3 & 0.0 & 0.0 & 20.0 & 24.2 \\
\hline $35-39$ & $30(25.2)$ & 31.1 & 33.3 & 33.3 & 27.3 & 25.5 & 25.0 & 15.0 & 28.6 & 24.2 \\
\hline$\geq 40$ & $8(6.7)$ & 4.1 & 11.1 & 22.2 & 7.3 & 8.5 & 0.0 & 0.0 & 5.7 & 4.5 \\
\hline Total & $119(78.8)$ & 49.0 & 29.8 & 11.9 & 7.3 & 31.1 & 2.6 & 19.9 & 23.2 & 43.7 \\
\hline
\end{tabular}


Table 6: Percent distribution of women, who have ever used any contraceptive method, by number of living children at the time of first use of contraception and age.

\begin{tabular}{|c|c|c|c|c|c|c|}
\hline \multirow[b]{2}{*}{$\begin{array}{l}\text { Age } \\
\text { in } \\
\text { years }\end{array}$} & \multirow[b]{2}{*}{$\begin{array}{l}\text { Number } \\
\text { of ever } \\
\text { used }\end{array}$} & \multicolumn{5}{|c|}{$\begin{array}{l}\text { Number of children at the time of } \\
\text { first used }\end{array}$} \\
\hline & & 0 & 1 & 2 & 3 & $4+$ \\
\hline $15-19$ & 1 & 100.0 & 0.0 & 0.0 & 0.0 & 0.0 \\
\hline $20-24$ & 17 & 35.3 & 58.8 & 5.9 & 0.0 & 0.0 \\
\hline $25-29$ & 40 & 5.0 & 72.5 & 17.5 & 2.5 & 2.5 \\
\hline $30-34$ & 23 & 13.0 & 60.9 & 21.7 & 3.3 & 0.0 \\
\hline $35-39$ & 30 & 0.0 & 33.3 & 26.7 & 16.7 & 23.3 \\
\hline$\geq 40$ & 8 & 0.0 & 12.5 & 12.5 & 25.0 & 50.0 \\
\hline Total & 119 & 10.1 & 64.0 & 18.5 & 7.6 & 10.1 \\
\hline
\end{tabular}

However, $19.9 \%$ of women who have stopped using birth spacing contraceptives (pills or IUDs) have mentioned that they became pregnant while using traditional methods of contraceptives, and $11.9 \%$ of them have mentioned fear from the side effects of contraceptives as their reasoning for stopping using them (Table 7).

Table 7: Percent distribution of women's, who never used any contraceptives, by main reason for not using and women who stop using the contraceptives by main reason.

\begin{tabular}{|lll|}
\hline Reasons for not using & Number & Percent \\
\hline Want more children & 30 & 93.7 \\
\hline Newly married & 2 & 6.3 \\
\hline Total & 32 & 100.0 \\
\hline Reason for stop using & & \\
\hline Want more children & 65 & 43.0 \\
\hline Fear from side effect & 18 & 11.9 \\
\hline Become pregnant & 30 & 19.9 \\
\hline Husband/family opposed & 3 & 2.0 \\
\hline Not an efficient method used & 1 & 0.7 \\
\hline Difficult to find contraceptives & 2 & 1.4 \\
\hline Total & 119 & 100.0 \\
\hline
\end{tabular}

\section{Ever use family planning method}

Cross tabulation used to check for any correlations among selected sociodemographic characteristics for both the woman and her husband who ever used family planning methods. We found a positive relationship between women who planned their pregnancy and the use of family planning ( $\mathrm{p}=0.003)$, as they tend to use family planning more than those who does not plan to get pregnant at this time. Education was found to be significantly related to the use of family planning as those with higher education tend to use more family planning methods compared to the women with none or primary schooling education $(\mathrm{p}=0.048)$. Marriage years was also found to be significantly correlated with the use of family planning, as women in their first ten years of marriage tend to use birth spacing family planning more $(\mathrm{p}=0.005)$. Women's age was positively correlated with the use of family planning as women use family planning mostly between the age of 25 and 39 years old which is the reproductive age among women in this sample $(p=0.005)$. Positive attitude towards the use of family planning was a clear factor in increasing its use $(\mathrm{p}=0.038)$.

Table 8: Percent distribution of women's who everused contraceptives by sociodemographic characteristics and selected independent variables.

\begin{tabular}{|c|c|c|c|}
\hline .Characteristics & $\begin{array}{l}\text { No. of } \\
\text { Women } \\
\text { Ever used } \\
\text { (119) }\end{array}$ & $\begin{array}{l}\text { Percent } \\
\text { age } \\
\text { Ever } \\
\text { used }\end{array}$ & $\begin{array}{l}\mathbf{P} \\
\text { value* }\end{array}$ \\
\hline \multicolumn{4}{|c|}{ Wanting this pregnancy } \\
\hline Yes & 70 & 58.8 & \multirow{3}{*}{$0.003 *$} \\
\hline Later & 41 & 33.6 & \\
\hline Not at all & 8 & 7.5 & \\
\hline \multicolumn{4}{|c|}{ Postnatal care previous delivery $(n=110)$} \\
\hline Yes & 51 & 46.4 & \multirow{2}{*}{1.000} \\
\hline No & 59 & 53.6 & \\
\hline \multicolumn{4}{|c|}{ Women's age in years } \\
\hline $15-19$ & 1 & 0.8 & \multirow{6}{*}{$0.005^{*}$} \\
\hline $20-24$ & 17 & 14.3 & \\
\hline $25-29$ & 40 & 33.6 & \\
\hline $30-34$ & 23 & 19.3 & \\
\hline $35-39$ & 30 & 25.2 & \\
\hline$\geq 40$ & 8 & 6.7 & \\
\hline \multicolumn{4}{|c|}{ Women's Position towards family planning } \\
\hline Totally for & 34 & 28.5 & \multirow{4}{*}{$0.038^{*}$} \\
\hline For using & 64 & 53.8 & \\
\hline Neutral & 19 & 16.0 & \\
\hline Against using & 2 & 1.7 & \\
\hline \multicolumn{4}{|l|}{ Husband's Age } \\
\hline $20-29$ & 21 & 17.6 & \multirow{4}{*}{$0.021 *$} \\
\hline $30-39$ & 64 & 53.8 & \\
\hline $40-49$ & 27 & 22.7 & \\
\hline$\geq 50$ & 7 & 5.9 & \\
\hline \multicolumn{4}{|l|}{ Marriage years } \\
\hline$<1$ & 1 & 0.8 & \multirow{6}{*}{$0.005^{*}$} \\
\hline $1-4$ & 17 & 14.3 & \\
\hline $5-9$ & 40 & 33.6 & \\
\hline $10-14$ & 23 & 19.3 & \\
\hline $15-20$ & 30 & 25.2 & \\
\hline$\geq 21$ & 8 & 6.7 & \\
\hline \multicolumn{4}{|l|}{ Working status } \\
\hline Employed & 20 & 16.8 & \multirow{2}{*}{0.229} \\
\hline Non Employed & 99 & 83.2 & \\
\hline \multicolumn{4}{|c|}{ Husband level of education } \\
\hline $\begin{array}{l}\text { None or primary } \\
\text { schooling }\end{array}$ & 31 & 26.1 & \multirow{2}{*}{0.160} \\
\hline $\begin{array}{l}\text { Secondary } \\
\text { school/higher edu. }\end{array}$ & 88 & 73.9 & \\
\hline \multicolumn{4}{|l|}{ Women's education } \\
\hline $\begin{array}{l}\text { None or primary } \\
\text { schooling }\end{array}$ & 47 & 39.5 & \multirow{2}{*}{$0.048 *$} \\
\hline $\begin{array}{l}\text { Secondary } \\
\text { school/higher edu. }\end{array}$ & 72 & 60.5 & \\
\hline
\end{tabular}

*significant at $\mathrm{p}<0.05$ 
In relation to the husband characteristics, husbands' in younger age group tend to support more the use of family planning $(\mathrm{p}=0.005)$.

However, education of the husband did not give any significant correlation with women's ever use of family planning methods $(\mathrm{p}=0.160)$ (Table 8$)$.

\section{Unmet family planning needs}

Table 9 shows that around $66 \%$ of women had planned their pregnancy and are willing to be currently pregnant. However, 51 women $(33.8 \%)$ replied that they wanted this pregnancy to be in a later timing or not wanting to be pregnant at all.

Table 9: Planned pregnancy and unmet family planning needs.

\begin{tabular}{|c|c|c|c|c|c|c|}
\hline \multirow[b]{2}{*}{ Planned pregnancy } & \multirow[b]{2}{*}{$\begin{array}{l}\text { Percent } \\
(\mathbf{1 0 0})\end{array}$} & \multirow[b]{2}{*}{$\begin{array}{l}\text { No } \\
(151)\end{array}$} & \multicolumn{4}{|c|}{ Family planning method before getting pregnant } \\
\hline & & & Not using & $\begin{array}{l}\text { Traditional } \\
\text { methods }\end{array}$ & $\begin{array}{l}\text { Modern } \\
\text { methods }\end{array}$ & \\
\hline \multicolumn{7}{|l|}{ Wanting this pregnancy } \\
\hline Yes & 66.2 & 100 & 27.7 & 33.7 & 38.6 & \\
\hline No & 5.3 & 8 & 2.4 & 25.0 & 62.5 & \\
\hline later & 28.5 & 43 & 2.4 & 40.6 & 59.5 & \\
\hline $\begin{array}{l}\text { Time welling to wait before } \\
\text { pregnancy }\end{array}$ & 100 & 43 & & & & \\
\hline I year & 27.9 & 12 & & & & \\
\hline 2 years & 27.9 & 12 & & & & \\
\hline 3 years & 30.2 & 13 & & & & \\
\hline 4 years & 9.3 & 4 & & & & \\
\hline 5 years & 2.3 & 1 & & & & \\
\hline 6 years & 2.3 & 1 & & & & \\
\hline $\begin{array}{l}\text { Reason to stop using before } \\
\text { getting pregnant }\end{array}$ & $\begin{array}{l}\text { Become } \\
\text { pregnant }\end{array}$ & $\begin{array}{l}\text { Fear from } \\
\text { side effects }\end{array}$ & $\begin{array}{l}\text { Husband } \\
\text { object }\end{array}$ & $\begin{array}{l}\text { Not efficient } \\
\text { method }\end{array}$ & $\begin{array}{l}\text { Difficult to } \\
\text { find }\end{array}$ & others \\
\hline Wanting child later & 52.4 & 31.0 & 4.8 & 2.4 & 2.4 & 6.8 \\
\hline Wanting no children more & 37.5 & 50.0 & 0.0 & 0.0 & 0.0 & 12.5 \\
\hline
\end{tabular}

The majority of women were willing to wait for one to three years before becoming pregnant. Out of those who is willing to postpone their pregnancy, $33.7 \%$ were using traditional methods of contraceptives, while the reasons for stop using contraceptives as mentioned by the women were that they just became pregnant (50\%) and they stopped using them due to their fear of side effects $(31 \%)$. For those who want to limit the number of their children, about two third were using modern contraceptives and half of them had stopped due to their fear of side effects.

Table 10 shows the significant factors associated with unmet needs which is mainly the total number of children as the more children women have the higher the need to postpone pregnancy or to limit the number of children $(\mathrm{p}=0.00)$.

Women's age was significantly associated with pregnancy planning as women with higher age are more likely to limit the number of children $(p=0.033)$. Additionally, women's marriage years was also found to affect pregnancy planning as women who have been married for longer time were more likely welling either to postpone pregnancy or to limit the number of children.
Table 10. Percent distribution of women who planned pregnancy and unmet family planning by selected factors.

\begin{tabular}{|c|c|c|c|c|c|}
\hline \multicolumn{6}{|c|}{ Women wanting this pregnancy } \\
\hline Factor & Yes & Later & $\begin{array}{l}\text { Not } \\
\text { at all }\end{array}$ & $\begin{array}{l}\text { Total } \\
\text { no. of } \\
\text { women }\end{array}$ & $\begin{array}{l}\mathbf{P} \\
\text { value* }\end{array}$ \\
\hline \multicolumn{6}{|c|}{ Marriage years } \\
\hline$<1$ & 100.0 & 0.0 & 0.0 & 8 & \multirow{6}{*}{0.022} \\
\hline $1-4$ & 66.7 & 33.3 & 0.0 & 36 & \\
\hline $5-9$ & 69.6 & 28.3 & 2.2 & 46 & \\
\hline $10-14$ & 67.5 & 30.0 & 2.5 & 40 & \\
\hline $16-20$ & 54.4 & 18.2 & 27.3 & 11 & \\
\hline$>21$ & 40.0 & 30.0 & 30.0 & 10 & \\
\hline \multicolumn{6}{|c|}{ Women's age } \\
\hline $15-19$ & 100.0 & 0.0 & 0.0 & 2 & \multirow[b]{6}{*}{0.033} \\
\hline $20-24$ & 74.2 & 25.8 & 0.0 & 31 & \\
\hline $25-29$ & 63.0 & 34.8 & 2.2 & 46 & \\
\hline $36-34$ & 75.9 & 24.1 & 0.0 & 29 & \\
\hline $35-39$ & 62.9 & 22.9 & 14.3 & 35 & \\
\hline$>40$ & 37.5 & 37.5 & 25.0 & 8 & \\
\hline \multicolumn{6}{|c|}{ Total no. of children } \\
\hline $0-1$ & 81.2 & 18.8 & 0.0 & 69 & \multirow{3}{*}{0.000} \\
\hline $2-3$ & 60.9 & 37.3 & 2.2 & 46 & \\
\hline $4+$ & 47.2 & 33.3 & 19.9 & 36 & \\
\hline
\end{tabular}

*significant at $\mathrm{p}<0.05$ 


\section{DISCUSSION}

This paper explores southern women in the Saudi Arabia, knowledge, attitudes and practices for family planning and contraceptives methods use in addition to their unmet needs for contraceptive use. The study shows that women have good knowledge of contraceptives especially modern methods, and positive attitudes towards the use of contraceptives. We have found that two third of women have ever used contraceptives, although close to half of them have used traditional family planning methods. Women's high level of education, women with positive attitudes towards family planning use, planned pregnancy, younger age of the women and less than 10 years of marriage were all positive factors associated with more ever use of family planning methods.

Women's knowledge of family planning methods, might be a very important key factor in increasing the use of contraception. ${ }^{13,25-28}$ Women's knowledge of family planning methods and contraceptives were found in the present study to be popular among women in the southern reign especially for the modern methods such as pills, injections and Intrauterine devices, which differs from the results conducted in the Al Qaseem in Saudi Arabia as they have found that $50 \%$ of the participants showed low knowledge concerning contraceptive methods. ${ }^{18}$ However, women's main source of family planning methods information was not coming directly from the health care providers, in fact several women in the study verbally revealed that the health care providers provide only family planning method upon women's request and answer shortly regarding women's concerns. The attitudes of health care providers towards family planning was found to be one of the main barriers for women's use of family planning as reported in many previous studies. ${ }^{29-31}$ When discussing with several Saudi southern women their information source, they revealed that they get their information through their friends and relatives experience, as well as through internet social media messages (personal communication, Saudi teacher). Social networks were previously discussed in several studies in relation to their effect on contraceptive use. They can have positive or negative effects in relative to friend's experiences in using family planning methods which can also influence women's decisions on choosing the appropriate methods. ${ }^{32-36}$ On the other hand, mobile technology and internet messages can be used effectively for supporting family planning use when it is goal directed and specific as recommended by recent studies in Cambodia. ${ }^{37}$ Present study revealed that women preferred to get their information from their husbands which indicates a good communication between women and their husbands regarding family planning use, in a study in Cambodia, the researchers have found that women who discussed and have better communication regarding family planning use with their husbands would have better contraceptive use and better results. ${ }^{38}$
Positive attitudes towards the use of family planning method were consistent with what was found by Al Sheeha study in Al Qassem region. ${ }^{18}$ Samandrari and others also found in a study in Cambodia, that women who believe that their husband is pro using family planning are more likely to use family planning methods than those who think that their husband's attitude is against using them. ${ }^{38}$

Our results regarding the ever use of family planning contraceptives showed that around two third of women had ever used contraceptives, out of them almost half had ever used pills and close to half had ever used withdrawal (traditional methods). Demographic factors such as women with younger age, younger husband's age, women's higher education, women's younger age of marriage were all positively correlated with more experience of using contraceptives. Demographic factors were also found to be positively correlated with family planning use in previous studies. ${ }^{39-41}$ Women who planned pregnancy were also found in the present study to have positive attitude toward the use of family planning, which was also discussed in several unmet family planning needs studies. ${ }^{42}$

The present study showed that about $34 \%$ of women did not plan their current pregnancy, $28 \%$ want to postpone this pregnancy for one to three years, while the rest welling to limit their number of children. According to the definition of unmet family planning need; this is considered unplanned pregnancy of the current or last pregnancy. ${ }^{42}$ Fear of side effect was found to be one of the major women's concerns for none use of contraceptives in several studies as an important reason to stop using contraceptives. ${ }^{42-46}$ In this study, women fear from side effects might be related to misinformation because the main source of information they get is not from the health care provider. Additionally, women tend to be spectacle from asking the health care provider regarding family planning methods and prefer to ask their friends and they depend on their husbands for choosing the appropriate method. Similarly, other studies have found that misinformation was a reason to stop using contraceptive, such as a study that was conducted in Nigeria. ${ }^{46}$ Stopping using Contraceptives could be also related to contraceptive failure, which is when women who are willing to postpone pregnancy became pregnant while using contraceptives. This was found in one report measuring unmet needs from the DHS studies among eight countries from different developing countries and recently by Ajong and the others. ${ }^{42,44}$ Factors that were associated in this study with unmet needs were marriage years, women's age and total number of children. Women's age was found to be an associated factor for unmet family planning need by Brady and the others in 2009 report. $^{44}$ Number of living children was significantly associated in a study in Cameron, which has found that women who have more children need to postpone or to limit the number of children, which indicates an unmet need. ${ }^{42}$ Marriage years usually comes 
with both women's age and parity as it's expected with increasing marriage years, women will be older and thus the need for limiting the number of children or postponing would be higher.

\section{Strengths and limitations of study are}

The high response rate is considered a strength of this study. However, one has to acknowledge that women's answers might have been affected because they were at the Obstetric clinic already. Furthermore, social desirability bias might be significant here. Men knowledge and attitudes were difficult to explore in this study, which might give a clear perspective and better future health plans.

\section{CONCLUSION}

Women in the southern region have quite fair knowledge of modern family planning and positive attitudes, although two third of women have ever used contraceptives, unmet need still there by $34 \%$ of them. Health strategies and programs on family planning need to be organized in order to meet women's and family needs and better focus concerning health care provider's family planning counselling and information given is required. Further studies are required concerning Sothern Men attitudes and knowledge of family planning.

\section{ACKNOWLEDGMENTS}

The study was facilitated by the Obstetrics and Gynaecology out-patient clinics by the general staff and nurse-in-charge.

\section{Funding: No funding sources}

Conflict of interest: None declared

Ethical approval: The study was approved by the Research Ethical Committee at the Armed Forces Hospital in the Southern Region, prior to the research being conducted

\section{REFERENCES}

1. United Nation Entity for Gender equality and empowerment for women. Convention of the Elimination of All Forms of Discrimination against Women. Available at http://www.un.org/womenwatch/daw/cedaw/text/eco nvention.htm

2. Abou Zahr C. Some thoughts on ICPD+5. Bull World Health Organ. 1999;77(9):767-770.

3. Ahmed S, Li Q, Liu L, Tsui AO. Maternal deaths averted by contraceptive use: an analysis of 172 countries. Lancet. 2012;380 (9837):111-125.

4. Potts M. Family planning is crucial to child survival. Network (Research Triangle Park, NC). 1990 Dec;11(4):2.

5. Rutstein SO. Fertility Levels, Trends and Differentials 1995-1999. Calverton, MD, USA. ORC
Macro; 2002. Available at https://dhsprogram.com/pubs/pdf/CR3/cr3.pdf.

6. DaVanzo J, Hale L, Razzaque A, Rahman M. The effects of pregnancy spacing on infant and child mortality in Matlab, Bangladesh: how they vary by the type of pregnancy outcome that began the interval. Popul Stud (Camb). 2008;62(2):131-154.

7. Ory HW. The noncontraceptive health benefits from oral contraceptive use. Fam Plann Perspect. 1982;14(4):182-4.

8. Dayal M, Barnhart KT. Noncontraceptive benefits and therapeutic uses of the oral contraceptive pill. Semin Reprod Med. 2001;19(4):295-303.

9. Jensen JT, Speroff L. Health benefits of oral contraceptives. Obstet Gynecol Clin North Am. 2000;27(4):705-721.

10. John WR. Population: an introduction to concepts and issues. $8^{\text {th }}$ Ed. Wadsworth Thomson learning, U.S.A;2002.

11. World Health Organization. Health education in health aspects of family planning. Technical Report Series No. 483. 1971.

12. Ajzen I. The theory of planned behavior. Organizational behavior and human decision processes. 1991 Dec 1;50(2):179-211.

13. Dabral S, Malik SL. Demographic study of Gujjars of Delhi: IV. KAP of Family Planning. J Hum Ecol. 2004;16(4):231-7.

14. Khraif RM. Fertility in Saudi Arabia: levels and determinats. A paper presented at : XXIV General population Conference-Salvador- Brazil;2001. Available at http://archive.iussp.org/Brazil2001/s60/S62_03_khra if.pdf

15. Population Reference Bureau. World Population Data Sheet. Washington, DC: PRB. 2001. Available at http://www.prb.org/pdf15/2015-world-populationdata-sheet_eng.pdf

16. DeJong J, Bashour H, Benkirane M, Ghanem M, Gherissi A, Zurayk H. DAWN Regional Advocacy Tools: Sexual and Reproductive Health and Rights Advocacy in Egypt, Lebanon, Morocco,Oman, Syria, Tunisia and Yemen. DAWN. Suva (Fiji). 2015. Available at https://www.dawnnet.org/feministresources/sites/default/files/resources/20150615_RA T_MENA.pdf

17. Department of Statistics [Jordan] and ICF International. Jordan Population and Family Health Survey 2012. Calverton, Maryland, USA;2013. Available https://dhsprogram.com/pubs/pdf/FR282/FR282.pdf

18. Al Sheeha M. Awareness and use of contraceptives among saudi women attending primary care centers in Al-qassim, saudi arabia. Int J Health Sci. 2010 Jan; $4(1): 11$.

19. Albezrah NA. Use of modern family planning methods among Saudi Women in Taif, KSA. Int. J Reprod Contracept Obstet Gynecol. 2015;4(4):990-4.

20. El-Zanaty, Fatma and Ann Way. (2009). Egypt Demographic and Health Survey 2008. Cairo, Egypt: 
Ministry of Health, El-Zanaty and Associates, and Macro International. Available at https://dhsprogram.com/pubs/pdf/fr220/fr220.pdf

21. Petro-Nustas W. Men's knowledge of and attitudes toward Birthspacing and Contraceptive use in Jordan. Gutlmacher. 1999;25(4):181-5.

22. Mahadeen AI, Khalil AO, Hamdan-Mansour AM, Sato T, Imoto A. Knowledge, attitudes and practices towards family planning among women in the rural southern region of Jordan/Connaissances, attitudes et pratiques des femmes en matière de planification familiale dans le sud rural de la Jordanie. Eastern Mediterranean Health J. 2012 Jun;18(6):567-72.

23. Jaffer YA, Afifi M, Al Ajmi F, Al Ouhaishi K. Knowledge, attitudes and practices of secondaryschool pupils in Oman: II. reproductive health. East Mediterr Health J. 2006 Jan-Mar;12(1-2):50-60.

24. Donati S, Hamam R, Medda E. Family planning KAP survey in Gaza. Soc Sci Med. 2000 Mar;50(6):841-9.

25. Conde-Agudelo A, Balizán JM. Maternal morbidity and mortality associated with interpregnancy interval: cross sectional study. BMJ. 2000;321:12559.

26. Gillespie DG. Whatever happened to family planning, and, for that matter, reproductive health? Int Fam Plan Perspect. 2004;30(1):34-38.

27. Edwards JE, Oldman A, Smith 1, McQuay HJ, Moore RA. Women's knowledge of, and attitudes to, contraceptive effectiveness and adverse health effects. Br J Fam Plann. 2000;26(2):73-80.

28. Moos MK, Bartholomew NE, Lohr KN. Counseling in the clinical setting to prevent unintended pregnancy: an evidence-based research agenda. Contraception. 2003;67:115-132.

29. Speizer IS, Hotchkiss DR, Magnani RJ, Hubbard B, Nelson K. Do service providers in Tanzania unnecessarily restrict clients' access to contraceptive methods?. Int Fam Plann Perspect. 2000 Mar 1:1342.

30. Frost JJ, Singh S, Finer LB. Factors associated with contraceptive use and nonuse, United States, 2004. Perspect Sexual Reprod Health. 2007 Jun;39(2):90-9.

31. Frost JJ, Darroch JE. Factors Associated with Contraceptive choice and inconstant methods use, United States, 2004. Perspect Sexual Reprod Health 2008;40(2):94-104.

32. Doms M, Vanavermaet E. Majority influence, minority influence and conversion behavior:a replication. J Experiment Soc Psychol. 1980;16(3):283-292.

33. Manski CF. Dynamic choice in social settingslearning from the experiences of others. J Econometr. 1993;58(1-2):121-136.

34. Bongaarts $\mathbf{J}$ and Watkins SC. Social interactions and contemporary fertility transitions. Population Dev Rev. 1996; 22(4):639-682.
35. Montgomery MR, Casterline JB. Social learning, social influence, and new models of fertility, Population Dev Rev. 1996;22(Suppl.):151-175.

36. Behrman JR, Kohler HP, Watkins SC. Social networks and changes in contraceptive use over time: evidence from a longitudinal study in rural Kenya. Demography. 2002; 39(4):713-738.

37. Smith C, Vannak U, Sokhey L, Ngo TD, Gold J, Free C. Mobile Technology for Improved Family Planning (MOTIF): the development of a mobile phone-based (mHealth) intervention to support postabortion family planning (PAFP) in Cambodia. Reprod Health. 2016 Jan 5;13(1):1.

38. Samandari G, Speizer IS, O'Connel K. The role of social support and parity in contraceptive use in Cambodia. Int Perspect Sexual Reprod Health. 2010;36(3):122-131.

39. Gereltuya A, Falkingham J, Brown J, Determinants of current contraceptive use and method choice in Mongolia. J Biosoc Sci. 2007;39(6):801-817.

40. Chandhick N, Dhillon BS, Kanbol I, Sevena NC. Contraceptive knowledge, practices and utilization of services in the rural areas of India (an ICMR task force study). Indian J Med Sci. 2003;57(7):303-310.

41. Khan S, Mishra V, Arnold F, Abdelrrahim N. Contraceptive Trends in Developing Countries, Calverton, MD, USA:ORC Macro;2007. Available at http://www.who.int/reproductivehealth/topics/infertil ity/DHS-CR9.pdf

42. Ajong $\mathrm{AB}$, Njotang PN, Yakum MN, Essi MJ, Essiben F, Eko FE, Kenfack B, Mbu ER. Determinants of unmet need for family planning among women in Urban Cameroon: a cross sectional survey in the Biyem-Assi Health District, Yaoundé. BMC Women's Health. 2016 Jan 20;16(1):4.

43. Campbell M, Sahin-Hodoglugil N, N, Potts, M. Barriers to fertility regulation: a review of the literature. Studies Fam Plann. 2006;37(2):87-98.

44. Bradley SE, Schwandt H, Khan S. Levels, trends, and reasons for contraceptive discontinuation. DHS analytical studies. Calverton, Maryland, USA: ICF Macro.2009;20.

45. Darroch JE, Sedgh G, Ball H. Contraceptive technologies: Responding to women's needs. New York: Guttmacher Institute. 2011 Apr;201(1).

46. Diamond-Smith N, Campbell M, Madan S. Misinformation and fear of side-effects of family planning. Culture, Health Sexuality. 2012 Apr 1;14(4):421-33.

Cite this article as: Dhaher EA. Family planning KAP survey in the Southern Region of Saudi Arabia. Int J Reprod Contracept Obstet Gynecol 2017;6:4798-807. 